\title{
Representation and De-legitimation in Semi-democratic Regimes: The Case of the Arab Citizens in Israel
}

\author{
Salim Brake \\ School of Political Sciences, University of Haifa, Israel
}

Copyright $@ 2018$ by authors, all rights reserved. Authors agree that this article remains permanently open access under the terms of the Creative Commons Attribution License 4.0 International License

\begin{abstract}
In this article, I offer a brief examination of the political model in Israel and review Arab representation in the Knesset on the basis of the model I propose for describing Israel's political system-that of the semi-democratic regime. I do not believe that the models proposed by other scholars are applicable to the Israel case. My assumption is that the parliamentary representation of Arabs in Israel is blocked and ineffective; hence, Israel cannot be seen as a full democracy. I will review the evolution of Arab parliamentary representation in Israel, its function, and its outcomes as a test case for the claim of the manipulation of representation and exclusion from the political sphere. I cannot discuss all the aspects of the Israeli regime that lead to this proposed model, but will focus on the patterns and trends in Arab Knesset membership, until recently, as a blatant example of a semi-democracy. I will assert that the Arabs' exclusion from the centers of political power means that Israel cannot be a democratic and egalitarian regime, but only an ersatz democracy, whose goal is to paint Israel as a democracy for external consumption, but nothing more.
\end{abstract}

Keywords Semi-Democracy, Representation, Ethnic Minorities, De-legitimation, Arabs in Israel, Palestinians

\section{Introduction}

Is it possible for democracy to exist without a constitution that defends individual's rights from the tyranny of the majority? Does a constitution guarantee this protection, if yes, then in which conditions? Either way, is it possible for real democracy to occur in the absence of central constitutional section that protects and anchors individual's rights and freedoms? A more annoying question is; can real democracy exist in a political atmosphere and among public opinion that most of it holds non-democratic attitudes and even anti-democratic ones

\section{from time to time?}

Robert Dahl [1] has concluded the basic conditions for the existence of democracy: some of them are effective participation, voting equality, and control the agenda. All these along with political culture which based on respecting other's rights, perception of equality as a value as well as defending individual's interests and properties.

Despite its commitment, Israel has avoided adopting a constitution, reinforcing the inferior status of the Arabs within the state by fostering set of rules and actions that have led to this condition and status. The most prominent of these rules is the continuation of implementing emergency regulations since the establishment of the state and until this day, regulations that diminish the real meaning of democracy, especially in relation to Arabs status and their basic rights. Most of the Israeli elite viewed and still viewing Arabs as undesirable minority. Accordingly, attitudes towards Arabs in Israel have fluctuated between hostility and alienation. All this together with additional other flaws such as religious compulsion, the existence of occupation will be more than 50 years.

Given such condition, does Israel's self-declaration as a democratic state reliable? Is it strictness to fulfill the formal rules such as elections and limited extent of power separation enough for defining Israel as a democratic state?

Many researchers consider the Israeli regime either as a kind of minimal democracy (Noeberger, [2]) or as a "low model of democracy" (Samooha, [3]), and some even completely reject the definition of Israel as a democratic state (Peled \& Shafir, [4]; Yiftachel \& Ghanem, [5]). All these researchers, who are Jewish, express difficulties accepting the contradiction between the very formal rules of democracy and the non-democratic essence of Israel as a state.

I suggest a different explanation for the nature of the Israeli regime, which I believe as more convening, and it is the Semi-Democracy model, that is to say an imitation of the western democratic model which is liberal in its nature, 
with a constant attempt to conceal the anti-democratic essence of the regime by declaration of commitment for basic democratic rules, or continuous attempt of presenting the fact of fulfillment parliamentary election as the most import aspect of democracy, while neglecting essential flaws mentioned above, along with a high level of political violence, severe processes of other's de-legitimation, and even incitement of government leaders against minorities, against civil society organizations, and against the left side parties, as we have been witnessing during the last decade.

Therefore, Semi-Democracy is considered or would be a regime model committed only to formal parliamentary rules of democracy that are based on enlistment of public opinion by the media, which is directed by the governmental elite, as well as on the ability to change the game rules in unequal and unfair ways by changing legislation using the constant available majority and employing violent manners which are not obligated to values of respect of minorities' rights and not even to essential commitment for respecting the very basic rights of the individual.

There are more tangible examples of why the State of Israel should be classified as a semi-democratic regime than those can be mentioned here. They include: Israel's character as a state of ethnic stratification that is not committed to the values of general civic equality; ${ }^{1}$ its definition as a Jewish state, which implies a significant degree of religious coercion that infringes civil liberties and, in particular, excludes Arabs because they are not Jewish and defines them as second-class citizens, no matter their actions or conduct; ${ }^{2}$ the general policy towards the Arabs; the discrimination against them in all fields of life; the existence of a "secret state"; their subjection to Emergency Regulations; and harsh manifestations expressions of racism, including by leaders such as the Prime Minister, other ministers, and Knesset members. The occupation regime in the territories and acute militarization of Israeli society can be added to the mix. However, in this article, I will focus on patterns of representation and assert that although Israel is a semi-democratic regime that adheres to the formal rules of democracy, it is not committed to core democratic values such as civic equality.

The parliamentary representation of the Arab-Palestinian minority is limited in scope and effectiveness in two basic ways: its token and ineffective inclusion in the Zionist parties, intended to display a pretense of inclusion and legitimacy; and the exclusion of

\footnotetext{
${ }^{1}$ There are serious charges of discrimination in Israel against Jews of Arab and Middle Eastern and especially Ethiopian origin. This ethnic rift is one of the strongest divisions in the country, with discrimination in housing, employment, standard of living, education, and other fields. For a broader discussion, see, for example, Smooha [6].

${ }_{2}$ The clearest case of discrimination against the Arab citizens, based only on religion, is that of the Druze, who serve in the military yet are nevertheless victims of discrimination in all fields of life and excluded from most sectors of the economy. The Druze villages are in the four lowest clusters of the socioeconomic scale, like all other Arab localities.
}

the Arabs' substantive representatives from centers of influence and government power. I will assert that the Arab representation in the Knesset is scarcely effective, because of the policy of distancing them from the political arena. Several means contribute to this ineffectiveness:

- The disproportionately low level of Arab representation in the Knesset

- The policy of ineffective and token microcosmos representation in the Zionist parties, which severs these parliamentarians' interests from those of the Arab citizens

- The shunting of Arab parliamentarians to the sidelines of the Knesset and distancing from any influence on the coalition or on government policy

- The delegitimization of the representatives selected by the Arabs themselves, as a follow-up to the effort to delegitimize the Arab citizens themselves

In what follows, I will briefly review the changing patterns of Arab parliamentary representation since Israel's founding. I will also present data about Arab Knesset membership and Arab MKs' presence in Knesset organs and posts.

\section{Methodology}

The research is based mainly on a series of interviews I conducted with several members of Knesset (MKs), both Arab and non-Arab. These were open-ended interviews, recorded as audio files and transcribed. I also surveyed the work of Arab Knesset members, both those of Zionist parties and those affiliated with parties that represent the Arab sector. I found that neither group exerted a significant influence on Israeli politics, excerpt for the "blocking majority" and the short period of direct elections for Prime Minister - the exceptions that prove my basic assertions. It is not intended to further the welfare of the Arabs in Israel, but only to provide a false image that serves the semi-democratic regime by allowing it to present itself internationally as a representative democracy with equal rights for all.

For this purpose, I will review the Joint Arab List's parliamentary output over the past two years and examine several important cases that reveal its fecklessness as an effective representative of the Arab minority in Israel.

\section{Parliamentary Representation: Some Theoretical Background}

Much has been written about the essence and importance of representation, in democracy in general and in liberal democracy in particular. The first thinkers to discuss the topic were the philosophers of the social contract, primarily 
Hobbes and Locke, who emphasized that the people's representatives must be authentic, free, and committed to their constituents. Later, Montesquieu emphasized the salient importance of the laws related to representation and the franchise. He added that it is vital to regulate the candidates' identity, how and by whom they are chosen, and how they fulfill the requirement of substantive representation of those they represent (Montesquieu [7], p 223-233]). Other thinkers opposed participation by the masses in the democratic process and wanted to limit the franchise to the elite and upper class. These political philosophers encouraged various means to exclude the masses from the electoral process, including token representation for show. With this in mind, Burke, for example, supported what he called "virtual representation," which provides a pretense of representation without allowing the masses any real power. ${ }^{3}$

The literature has dealt extensively with the forms of representation, which can be descriptive, demographic, sociological, or symbolic. In any event, it is passive and not authentic, in contrast to the only model of representation that fits true democracy-active representation. ${ }^{4}$

Birch raises three questions about representation and its quality: 1 . Who must be represented? 2. How should a representative act? 3. How is a representative chosen? He stresses that elected representatives must emphasize the needs of those they represent (their representees) and faithfully express the latters' positions. In practice, this is the only form of representation relevant to the political arena, which is supposed to ensure the interests and desires of those represented. He notes that the behavior of elected officials is completely different from that of representatives in the other models. In order to determine whether a representative actively and faithfully represents the representees, three basic conditions must be examined:

1. The enlistment process: There must be several representative positions and several candidates, thus permitting free election of the representatives by the representees.

2. Competition: There must be real and fair competition between the candidates. The election process must provide the winning candidate with broad support among the representees.

3. Representation must be connected to the principle of accountability. Representatives must always be accountable to their representees to ensure their commitment to the latter.

\footnotetext{
${ }^{3}$ See, for example: Burke, E. "Speech on Bill for shortening the Duration of Parliaments"; "Speech on a motion made in the House of Commons the $7^{\mathrm{TH}}$ of May 1782, for a Committee to inquire into the State of Representation of the Commons in Parliament," in The Writing and Speeches of Edmond Burke [8, p. 132-133; 144-153].

${ }_{4}^{4}$ For a broad discussion of representation in its various forms, see: Philips [9]; Ruedin [10]; Birch [11]; Birch [12]; Pitkin [13]; Pitkin [14]. For a discussion of Arab representation in Knesset, see Brake [15]; Brake [16]
}

4. Building on the previous condition, representatives must report to their representees and act according to the charter provided them by their representees (Birch [8]).

In this study, we will see that Arab representation in the Zionist parties and in the satellite lists formed in the 1950s did not meet these criteria. Hence, the Arab representation in these frameworks was barren and not active.

\section{Arab Representation in the Knesset}

When Israel conducted its first census, in November 1948 , the population included 156,000 Arabs, or $18 \%$ of the residents of the newly formed state. Ben-Gurion leaned towards denying Arabs the right to vote for the Knesset, but gave in to the constraints imposed by the UN Partition Resolution and the pressure of left-wing factions, such as Maki (the Israel Communist Party) and Mapam, which supported the Arab right to vote. The decision to enfranchise the Arabs was meant to prevent Israel from being seen as a Herrenvolk democracy.

The efforts to minimize the Arabs' power in the Knesset followed two main paths: (1) promoting token microcosmos representation without influence, by means of Arab satellite lists associated with the major parties or the promise of symbolic sociological representation through the Zionist parties; (2) excluding Arabs from the centers of political power and preventing the formation of independent Arab lists. This led many Arabs to vote for Maki as the only alternative to the ruling party and the satellite Arab lists.

\section{Manipulation of Arab Representation}

Before the elections for the Constituent Assembly (which became the first Knesset), Mapai ${ }^{5}$ set up an Arab department made up of former intelligence officers and Jews from Arab countries who engaged in partisan politics; it was tasked with controlling the Arab electorate and exploiting the Arab vote to the advantage of the ruling party. This led to the idea of the "minority lists," which were satellite lists established by Mapai, based on religion (Muslims, Christians, and Druze ${ }^{6}$ ); their candidate were

\footnotetext{
5 The Land of Israel Workers' Party (Mapai), headed by Ben-Gurion, disbanded in 1965, and the Alignment party was formed out of its remains. In the 1980s, the Alignment, too, was disbanded, and only the Labor party, which still exists, remained.

6 The Druze minority is about $8 \%$ of the Palestinian population. Their leaders decided to co-operate with the Zionist institutions since the $30^{\text {Th }}$ of the $20^{\mathrm{TH}}$ decade because considerations, like defense from their Muslim and neighbors. They served the Zionist agencies in different fields, like military and intelligence, and served as agents for land owning from Palestinians. In 1956, the Druze minority was included in the duty of military service, like the Jewish majority. These reasons made the Druze more acceptable in the Israeli parties.
} 
individuals who cooperated with Israeli intelligence and government elements, brokered land purchases by Jews, and the like. This generally traditional and ethnic leadership was rewarded for its assistance to the Zionist party and its institutions in the past. They served as "propaganda agents" 7 for Israel vis-à-vis the world, because they gave many speeches in favor of Israel and its fair and equal treatment of the Arabs. At a time when the Arabs were actually under harsh military rule, deprived of most civil rights such as freedom of movement, expression, and property (massive land expropriations), and with their education and culture under the thumb of the security services. The military government and the security services made fervent efforts to encourage Arabs to vote for these lists and made the provision of various services dependent on the "right" slip in the ballot box (Brake [16]; Baumel [17]; Ozacky-Lazar and Baumel [18]).

As stated, these lists were headed by individuals who were under obligation to the ruling party and enjoyed no freedom in their Knesset speeches or activities; their votes were always dictated to them by the Mapai bosses. This provided the party with three or four additional compliant MKs who supported the coalition without any compensatory benefits for the Arab population they ostensibly represented.

This method worked effectively for the ruling party, which barred Arabs from membership until 1973. But the abolition of the military government in 1966 cut into the Arab vote for this list and ways were sought to recover it. Before the elections for the Ninth Knesset, the Alignment decided to use a method that had been effective with the Mizrahi Jews: a promise of representation. This means that the party chooses a representative whom it deems will support its policy and can enlist votes for it, and includes him on its Knesset list. This method of passive or symbolic representation achieves several objectives: First, it ensures that the representative will be someone favored by the party and in its interest to promote. Second, it ensures the representative's complete dependence on the party, in a patron-client relationship (Scott [20]); the party can replace him if he shows signs of independence. Third, the representative has no responsibility towards his ostensible constituency and thus no motivation to act effectively to promote their interests; this ensures that he will not fight about core issues important to his ostensible representees. Moreover, it provides the party a democratic veneer of

\footnotetext{
${ }^{7}$ The Arab MKs on these lists were proud of being agents of pro-Israel propaganda and glad to have their speeches translated by the Information Office (see: Baumel, [17], and primarily what the head of one of these lists, Abd el-Aziz el-Zouabi [19] wrote in his memoirs). The government exploited them to deflect criticism of its policy against the Arabs, who were subjected to a military government and severe limitations to their freedom and rights as well as massive land expropriations. These MKs' fawning speeches and declarations produced major propaganda benefit for the state.
}

integration and thus governmental legitimacy as egalitarian.

Other parties adopted this method over the years. Even right-wing and extreme right-wing parties have included Arabs on their Knesset lists, though only Druze who meet strict criteria. ${ }^{8}$

In the right-wing parties, the minority representative (always Druze, as mentioned) must clearly distinguish himself from the Arabs. (The Labor Party, too, has reserved separate places on its list for an Arab and a Druze, as part of its "divide and rule" policy.) Druze MKs make frequent declarations on behalf of the Druze and their rights, but consistently avoid addressing the rights of the Arab population. In many cases, they work actively against the Arab sector, not only through declarations but also through sponsorship of bills and votes. Two clear examples of this are a Druze MK who belongs to an explicitly racist party that calls for revoking the citizenship of Arab citizens and limiting their civil rights (Yisrael Beiteinu) and a Druze MK from the Likud who repeatedly attacks the Arab citizens, accuses them of betraying the country, makes belligerent declarations against them, and repeatedly attacks and disparages their Knesset representatives. These MKs act against the citizens among whom they live and whom they meet in their daily routines; they support every bill or parliamentary or government action that infringes their rights, even when it impacts Druze rights as well. Druze representation is microcosmos and passive exactly like representation of the other minority factions. They do very little for their community and concentrated in their own career. Druze opinion on these representatives is not a praise for the at all (only 18\% were satisfied of them (Brake, [15]).

\section{The Effects of Manipulating Representation}

The phenomenon of symbolic, mirror, or demographic representation may have three main characteristics (Figure 1). The first is political corruption, which is a direct result of the link between the party machinery and the political operative. The political operative seeks favors for himself and his henchmen. For example, he requests payments or

\footnotetext{
${ }^{8}$ Parties such as the Likud, Yisrael Beiteinu, and Kulanu have Druze representatives, who are "Druze in the eyes of the Jews and Arabs in the eyes of the world," as a former Druze MK stated. Druze candidates for these parties must "have a background," meaning they must have assisted the Zionist movement or ruling bodies, especially the intelligence services, or be the sons of those who did so. The Likud has set two conditions for Druze candidates: they must have lost a family member who served in the IDF or be former senior officers. These Druze candidates represent themselves as having right-wing views that generally conflict with those of most of the Druze population (Brake [15]) and are estranged from or even hostile to the rest of the Arab sector in their activities and statements. For a broader discussion of this issue, see Brake [12]
} 
fictitious positions for his allies, such as appointments to nominal posts of "ministerial advisors," "ministerial aides," and the like, where the only real job is to help the candidate promote his personal or partisan interests (Brake [16], [15]). The second is electoral corruption, expressed in bloc voting in party primaries for candidates the party wants to advance, while undermining the status of candidates it disfavors. This is the phenomenon generally known as "vote contractors"; the clan structure of Arab society gives a party operative outsize control of his extended family, whom he enlists on behalf of his political wheeling and dealing (for a broader discussion, see Brake [16]). Of course, during election campaigns these operatives, part of the patron-client system (Scott [20]), are expected to sweep in votes for the party from their group, with no relation to its members' ideological positions. This is reflected in the sharp swings from one election to the next between parties whose platforms are poles apart, in a consistent fashion that otherwise defies explanation (Brake [16]).

The second aspect of this phenomenon is the continual erosion of the ethnic group's political power. When many are maneuvered to support not only a party, but in fact specific candidates within the party, the group's political power is limited in a way that prevents it from negotiating with the party so as to promote its collective interests. For example, a group may support a Knesset candidate even though he espouses negative or hostile positions towards it. This explains the disparity between the number of Arabs registered in the Labor Party in the 1990s and early 2000s, on the one hand, and their scant influence on the party's policy towards Arabs, as reflected for instance in the events of October 2000 in which twelve Arab citizens were killed. The party enjoys a comfortable base of activity, a sort of "backyard," while significantly weakening the minority's electoral and political influence.

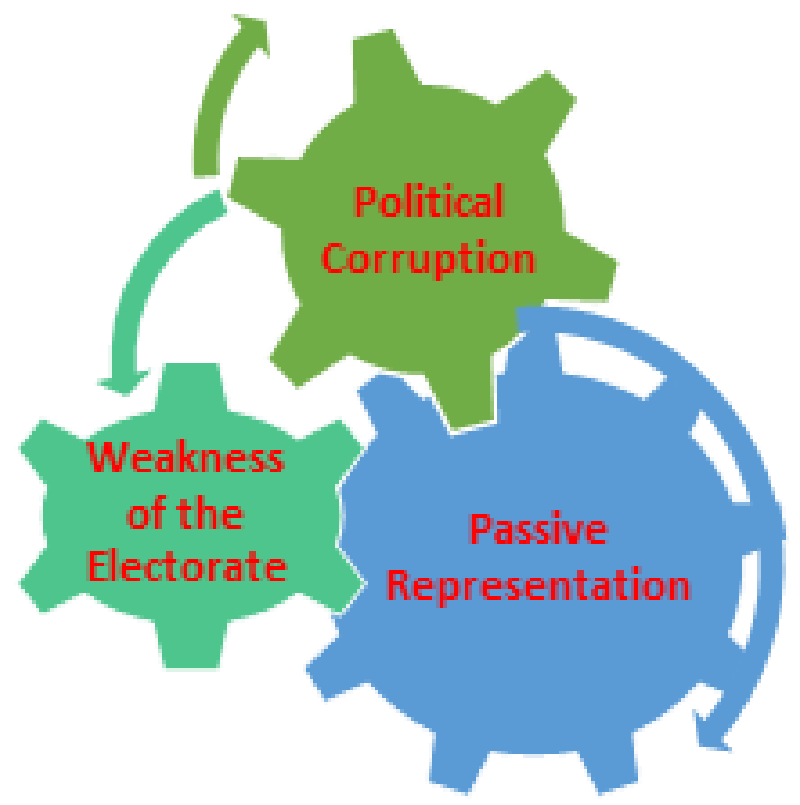

Figure 1. Representation, electorate and political behaviour

\section{Numerical Under-Representation}

Since the founding of Israel, the Arabs have always been underrepresented in the Knesset, even if we include the Arab MKs in Zionist parties. Over time, Arab Knesset membership has varied from $2.5 \%$ (the First Knesset) to the all-time high of $14 \%$ in the present Twentieth Knesset (list 1). In other words, the Arabs' numerical representation has ranged from one-sixth to more than two-thirds of their percentage in the population. 
The table below shows the Arab representation in the Knesset from 1949 to the present, by type of party (Figure 2). Note that the satellite parties set up by Ben-Gurion disappeared after failing to reach the electoral threshold for the Tenth Knesset. In practice, the Labor Party has accepted Arab members since the Ninth Knesset and has allocated the Arabs symbolic representation, just as Mapam had done since the 1950s. Even the right-wing parties, including the Likud, Kadima, and Yisrael Beiteinu, joined this trend over time; this will be discussed below.

List 1. Arab representation in the Knesset compared with their rate in the population.

\begin{tabular}{|c|c|c|c|c|c|c|}
\hline \multicolumn{7}{|c|}{ Arab Representation in the Knesset } \\
\hline Knesset \# & $\begin{array}{l}\text { Total Arab } \\
\text { MKs }\end{array}$ & Satellite Parties & Zionist Parties & $\begin{array}{c}\text { Arab } \\
\text { Representation } \\
\text { (Arab Parties) }\end{array}$ & $\begin{array}{l}\text { Proportion of } \\
\text { Arabs in Knesset }\end{array}$ & $\begin{array}{l}\text { Proportion of Arabs } \\
\text { in Israeli Population }\end{array}$ \\
\hline 1 & 3 & 2 & & 1 & $2.5 \%$ & $18.0 \%$ \\
\hline 2 & 7 & 5 & & 2 & $5.8 \%$ & $14.0 \%$ \\
\hline 3 & 8 & 5 & 1 & 2 & $6.7 \%$ & $11.0 \%$ \\
\hline 4 & 8 & 5 & 1 & 2 & $6.7 \%$ & $11.0 \%$ \\
\hline 5 & 7 & 4 & 1 & 2 & $5.8 \%$ & $11.0 \%$ \\
\hline 6 & 7 & 4 & 1 & 2 & $5.8 \%$ & $13.0 \%$ \\
\hline 7 & 7 & 4 & 1 & 2 & $5.8 \%$ & $14.0 \%$ \\
\hline 8 & 7 & 3 & 2 & 2 & $5.8 \%$ & $15.0 \%$ \\
\hline 9 & 7 & 1 & 4 & 2 & $5.8 \%$ & $15.0 \%$ \\
\hline 10 & 5 & 0 & 2 & 3 & $4.2 \%$ & $16.0 \%$ \\
\hline 11 & 7 & & 3 & 4 & $5.8 \%$ & $17.0 \%$ \\
\hline 12 & 6 & & 3 & 3 & $5.0 \%$ & $18.0 \%$ \\
\hline 13 & 8 & & 4 & 4 & $6.7 \%$ & $18.0 \%$ \\
\hline 14 & 12 & & 4 & 8 & $10.0 \%$ & $18.0 \%$ \\
\hline 15 & 12 & & 3 & 9 & $10.0 \%$ & $19.0 \%$ \\
\hline 16 & 11 & & 4 & 8 & $9.2 \%$ & $19.0 \%$ \\
\hline 17 & 11 & & 3 & 8 & $9.2 \%$ & $20.0 \%$ \\
\hline 18 & 14 & & 4 & 10 & $11.7 \%$ & $20.0 \%$ \\
\hline 19 & 12 & & 2 & 10 & $10.0 \%$ & $20.0 \%$ \\
\hline 20 & 17 & & 5 & 12 & $14.2 \%$ & $20.0 \%$ \\
\hline
\end{tabular}

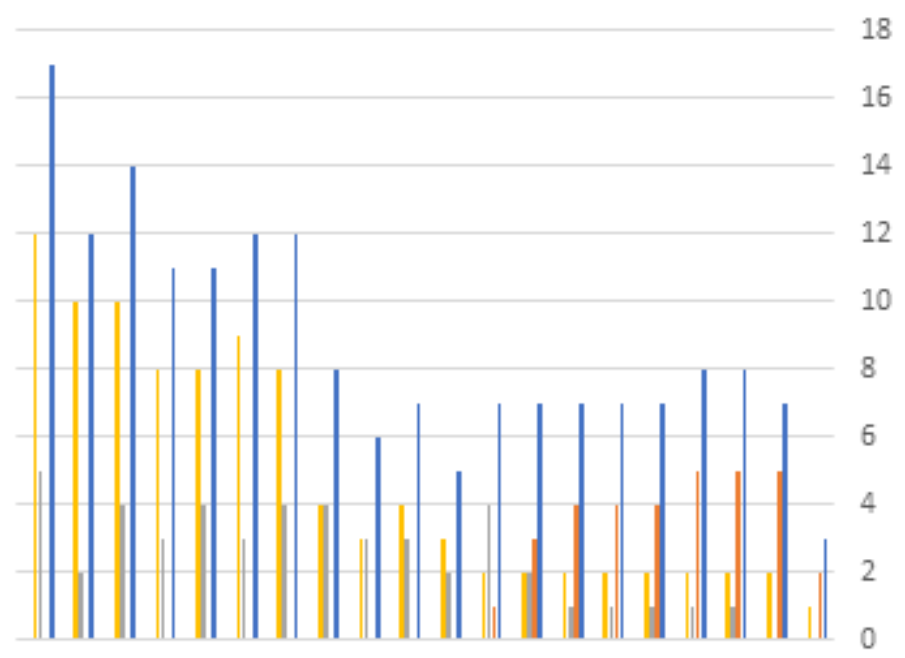

$201918171615141312111090807 \quad 6 \quad 5 \quad 4 \quad 3 \quad 2 \quad 1$

Bars: Yellow: Arab Representation (including the Communist Party); Gray: Zionist Parties; Orange: Satellite Lists; Blue: Total Arab MKs (Knesset 1-20)

Figure 2. Arab representation according to Party catigiries 
List 2. Arab MKs' Productivity compared to the productivity of the average MK

\begin{tabular}{|c|c|c|c|c|c|c|c|c|c|}
\hline \multicolumn{7}{|c|}{ Productivity of Members of the Sixteenth Knesset in Comparison with the Average MK } \\
\hline & $\begin{array}{c}\text { Parliamentary } \\
\text { questions } \\
\text { Written }\end{array}$ & $\begin{array}{c}\text { Parliamentary } \\
\text { questions } \\
\text { Oral }\end{array}$ & $\begin{array}{c}\text { Parliamentary } \\
\text { questions } \\
\text { Total }\end{array}$ & $\begin{array}{c}\text { Motions } \\
\text { for the } \\
\text { agenda }\end{array}$ & $\begin{array}{c}\text { Sponsored } \\
\text { bills }\end{array}$ & $\begin{array}{c}\text { Preliminary } \\
\text { Discussions }\end{array}$ & $\begin{array}{c}\text { First } \\
\text { Reading }\end{array}$ & $\begin{array}{c}\text { Bills } \\
\text { Passed }\end{array}$ & Speeches \\
\hline Overall Average & 35 & 3 & 38 & 33 & 43 & 8 & 1 & 2 & 167 \\
\hline By party & & & & & & & & & \\
\hline Selected categories & -3 & 0 & -3 & -4 & 28 & 1 & 0 & 1 & -50 \\
\hline $\begin{array}{c}\text { Women (gender } \\
\text { representation) }\end{array}$ & -18 & -2 & -20 & 0 & -2 & -6 & 0 & -2 & -4 \\
\hline $\begin{array}{c}\text { Arabs in Zionist } \\
\text { parties }\end{array}$ & 24 & 2 & 26 & 34 & -3 & 2 & -1 & -1 & 208 \\
\hline Arab parties & & & & & & & & \\
\hline Individual MKs & & & & & & & \\
\hline
\end{tabular}

\section{Ineffectiveness}

Knesset members elected as mirror or symbolic representatives tend to be ineffectual and do not act on behalf of the Arab minority, even when they are members of the ruling party. For example, there is harsh and systematic discrimination against Arabs in the Health Ministry. There has never been an Arab in any of the Ministry's fifty most senior positions. Who would believe that for four years the deputy health minister was the Arab MK Nawaf Masalha (Labor Party)? When I asked one of my interviewees about this, he could not explain why Masalha had never exerted in any influence in this vital ministry. There are too many other cases of this to detail here. One salient example is a deputy interior minister who had absolutely no influence on the master plans that stifled new construction in Arab towns, including his own.

At no time in the seven decades of Israel's existence have the Arabs been partners in the government. Arab Knesset members have been completely excluded from the centers of power and influence; even those from the ruling party have been forced to settle for symbolic positions devoid of real influence.

\section{Productivity}

This study's hypothesis is that MKs elected as mirror or symbolic representation are committed to their party and its interests and have a weaker commitment to the population they ostensibly represent. Their reelection depends on the party machinery that selected them, or that at least provided the political and other incentives that helped them reach the Knesset through the party. In exchange, they perform various services for it, such as getting people to turn out for the primaries and vote for the candidates preferred by the party or patron; canvassing for the party in general elections; and, of course, providing legitimacy to the party as the ostensible representative of the Arab minority. It is thus understandable that their parliamentary output would lag behind that of MKs elected through substantive representation. To corroborate this assertion, the parliamentary output of members of the Sixteenth Knesset was analyzed in several categories (list 2).

The conclusion is that these MKs (token Arab MKs in Zionist parties) are generally much less productive than the average lawmaker, including the MKs of the Arab parties. The three MKs in this category were also much less productive than female MKs elected to Knesset in slots reserved for women.

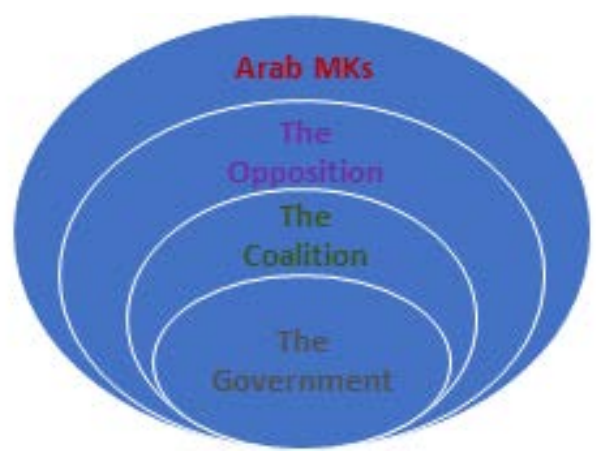

Figure 3. The Knesset’s Functional Structure

After Arabs were included in the Knesset lists of the Alignment (the successor to Mapai) and the Likud (since the Eighth Knesset in the late 1970s), these MKs have always sat on their party's back benches and been assigned to the less-important Knesset committees. They have never been at center stage and have never amassed power independent of the party machinery and patronage system (Figure 3).

Even though there have been Arab deputy ministers, these were symbolic positions with no real authority or control of budgets. ${ }^{9}$ The first Arab minister was appointed in 2000, but was soon forced to resign due to a corruption

\footnotetext{
${ }^{9}$ For a broader discussion of the symbolic and toothless positions of Arab deputy ministers, see: Brake [16]; Benziman and Mansour [21]; Baumel [17].
} 
scandal. ${ }^{10}$ An Arab was appointed culture minister in 2007. The public and other members of the Government treated him as lacking real authority. He was unable to register a single achievement for the Arab population. During and after his stint at the ministry, the culture and sport budget for the Arab sector remained almost nonexistent.

Arab MKs have never held meaningful posts in the Knesset. Until the Twentieth Knesset, no Arab MK was appointed speaker, coalition chair, leader of the opposition, opposition whip, or committee chair, except for the two MKs who chaired the Internal Affairs and Environment Committee for part of the Knesset term, on behalf of their party (MKs Salah Tarif and Raleb Majadle in interviews with the author). Only now has an Arab been named chair of the Committee on the Status of Women and Gender Equality; she is already complaining that there are elements attempting to minimize her authority and remove central issues from the committee's purview (MK Touma-Sliman in an interview with the author). Nor has an Arab MK ever served on important bodies such as the Judges' Nominations Committee or on a parliamentary committee of inquiry that does not focus on the Arabs. The clearest indication of the Arab MKs' weakness is the gross under-representation of Arabs on the Knesset payroll: only $2.5 \%$ in $2015,{ }^{11}$ far below the average for government ministries (9\% that year, when Arabs are $20 \%$ of the population).

The Labor Party, which received many Arab votes until the late 1990s was one of the leaders in the discrimination against and delegitimization of the Arabs. In the 1990s, the then-chair of Labor, Ehud Barak, openly declared that he did not see the Arabs as potential partners in his coalition and declined to meet their representatives. Despite this statement, he received $94 \%$ of the Arab vote in the direct elections for Prime Minister (Brake [16]).

The Arab MKs have never been able to reverse a decision to expropriate Arab land. Nor have they influenced the overall policy towards the Arab citizens (Benziman and Mansour [21]; Baumel [17]; [23]; Brake [15]). Even the Arab deputy ministers have had had no influence in their ministries.

Even in the field of legislation, Arab MKs have minimal influence. It is sufficient to consider the case of the Education, Culture, and Sports Committee in the Eighteenth Knesset to see this. The explanation for this is clear: every committee has, quite naturally, a Jewish majority, and a majority of the Jews are from the right-wing and Orthodox parties. Hence there is a committee majority automatically opposed to its Arab

\footnotetext{
${ }^{10}$ Minister Salah Tarif, a Druze who had been an IDF officer, was named to the post by the Labor Party because of his father's services in encouraging Druze to enlist in the IDF. Tarif was appointed minister without portfolio. In an interview with the author, he emphasized that he was given no authority at all and not even a minimal budget with which to function.

${ }^{11}$ Source: Knesset Research and Information Center [22]
}

members. Moreover, in several cases members of Labor blocked initiatives by Arab MKs that touched on the mechanisms of the total Jewish control of the Arab population, as in this case, where Arabs are excluded from decision-making and policy-making about education, even as it directly affects Arabs. ${ }^{12}$

In the past decade, the Knesset has enacted more than thirty racist and discriminatory laws; more than a hundred bills are in various stages of the legislative process. ${ }^{13}$ In general, the Arab MKs have no influence over any of this. Beyond the "robbery laws" that sanction the theft of Palestinian property in the occupied territories, the most prominent of which is the "Hasdarah" (retroactive legalization) Law, other measures were passed that injure Arab citizens, such as the amendment to the Planning and Construction Law (the "Kaminitz Law"). This amendment is a clear example of undemocratic majority rule; the "illegal" construction is the result of the obstacles piled up by the Planning Committees and the Interior Ministry and the lack of approved master plans for most Arab towns.

In addition to the numerous laws that directly harm the Arab minority, there are several bills that would limit Arab citizens' ability to take advantage of statutory provisions to achieve equality. A good example is an amendment to the Equal Employment Opportunity Law, which allows preference to military veterans (in practice this means preference for Jews over Arabs). This amendment offers additional evidence of the harm that "mirror" passive representation does to the sector to which the legislator belongs, given that one of the bill's sponsors is an Arab from an extreme right-wing party. It might make an impression that this amendment will be in the benefit of the Druze candidates, but it's not. The discrimination of the Druze candidates can't be corrected by more discrimination of the other Arab minorities. Furthermore, putting the competition among the Arab factions causes more tension among them and affects badly the Druze who live among the other Arabs.

This case is interesting because it represents the behavior of Arab MKs in right-wing parties, who not only fail to oppose such legislation but actually support it. In many cases, they cosponsor bills intended to harm the Arab population or its representatives in the Knesset. Moreover, the fact that right-wing parties accept only Druze on their Knesset lists serves the policy of ethnic division of the Arab minority and encourages antagonism within it. For example, an Arab (Druze) MK from Yisrael Beiteinu cosponsored a bill that would require all MKs to place an

\footnotetext{
12 The most recent case is of the newly released civics textbook, in which the Arabs are presented in a completely distorted manner, defined as a hostile minority and as a collection of ostensibly separate groups with a generally negative profile. No Arab took part in the approval of the textbook; even when an Arab was co-opted to the committee as a token, he was not invited to meetings; his influence, already minimal, was totally

${ }^{13}$ Source: Knesset website, bill sponsorship data processed by the author.
Souted.
} 
Israeli flag behind them in every public appearance in Israel. It is clear that this bill, like many others, targets the Arab MKs. This case of an Arab MK from a party whose platform flirts with fascism and expresses hostility towards the Arab population shows that the method of symbolic representation is effective not only in eroding the representation of minorities while seeming to be democratic, but can also injure those minorities specifically because of the presence of Arab representatives.

\section{Legal Maneuvers and Legislation Aimed at Clipping the Wings of Arab Representatives}

As early as the mid-1950s, Israel acted to prevent substantive Arab representation in the Knesset. Arabs who voted for Maki were harassed and kept under constant surveillance by the General Security Service. In the 1980s, when the Arabs began organizing politically and set up parties to run for the Knesset, a series of laws were enacted to restrict the Arabs' options for representation and the substance of that representation. The following partial list exemplifies the trend.

Amendments to the Basic Law: The Knesset: In 1985, the Basic Law: The Knesset, was amended to include Section 7a, whereby a list can be barred from running for the Knesset if it does not recognize Israel as a Jewish and democratic state. All potential MKs, including Arabs, must accept this as a condition of their candidacy. The new clause was aimed at the Arabs; the "democratic" stipulation has remained a dead letter, given that some parties, notably the Ultraorthodox, do not accept the democratic regime and do not follow its rules. The amendment raised the bar for representation by forcing Arab political activity to clear this hurdle. Over the years it has been repeatedly fine-tuned so as to further restrict Arab representation of in the Knesset. ${ }^{14}$

The MK Immunity Law: The MK Immunity Law was revised in reaction to fraudulent voting by two MKs from the Likud, ${ }^{15}$ the ruling party at the time. But the amendment undermined the Arab MKs' ability to function, because it stipulated that MKs who have been indicted must request the Knesset to grant them immunity (instead of receiving it automatically), leaving them at the mercy of the Jewish majority. Clearly this change has also had a chilling effect.

The MK Suspension Law: In the summer of 2016, the Knesset passed the Suspension Law (which the media and

\footnotetext{
14 The law has been amended several times and now allows the disqualification of individual candidates on a slate, including one who has visited a country defined as an "enemy state."

${ }^{15}$ The Likud was formed by the merger of Herut, founded by Menachem Begin, the Liberals, and Ariel Sharon's Shlomzion faction. For the past two decades, it has been led by Benjamin Netanyahu.
}

observers referred to as the "Arab MK elimination law”), under which a Knesset majority can suspend a sitting MK. The law has a significant chilling effect and has already been used against an Arab MK, who was eventually forced to resign his seat.

Citizen who elect their Knesset representative are appointing a delegate or, in Hobbes' term, trustee. The possibility of suspending a legislator effectively neutralizes the concept of representation and undermines the foundations of the democratic regime. It is a substantive violation of the principle of representation, which is subjugated to the whim of the majority; henceforth Arab MKs face the constant threat of expulsion. The future threat is that the current requirement of a supermajority may be amended, producing a situation in which it is easier for the Jewish majority (which generally votes automatically against Arab MKs) to expel an Arab MK. In light of past experience, as with the aforementioned Section 7a of the Basic Law, amended several times in order to eroding Arab representation and make it possible to disqualify Arab candidates (and not only lists, as the original clause required), this concern is certainly justified. ${ }^{16}$ In fact, bills to reduce the required supermajority have already submitted. $^{17}$

Proposed Basic Law: Israel as the Nation-State of the Jewish People: The past few years have been marked by debates about this proposed Basic Law, which would strengthen the state's Jewish identity at the expense of the democratic values expressed in previous amendments to Basic Laws, which define Israel as a Jewish and democratic state. ${ }^{18}$ The law would require that courts give precedence to the state's Jewish character over democratic values such as equality and civil liberties.

The bill, sponsored by the Prime Minister and senior ministers and enjoying overwhelming support from the coalition, is a concrete expression of Israel's ethno-national and anti-liberal character. The proposed law is explicitly intended to provide an imprimatur to discriminatory processes and laws that violate democratic norms and that the government wishes to promote.

\section{Delegitimization of Arab MKs}

Whenever the Arabs have taken democracy seriously, they have been burned by their naïveté, but not for long time. As noted, Ben-Gurion followed a two-pronged policy

\footnotetext{
16 For a discussion of the changes to this clause, including the "Bishara Amendment” of 2000, see: Kremnitzer [24].

17 Several bills have been submitted that are similar to that of MKs Cohen and Oren (P/20/2881), which would allow the suspension of an MK by a majority of $80 \mathrm{MKs}$, for a period of time that is not necessarily limited, and could mean the remainder of the Knesset term.

${ }^{18}$ Israel was first defined as a Jewish state in the amendment to Basic Law: The Knesset in 1985. Its Jewish identity was subsequently incorporated into other basic laws.
} 
to limit the Arab electorate: manipulating their representation by attracting Arab voters to inauthentic satellites of his own party and preventing active representation by placing certain parties beyond the pale, as in his notorious "without Herut and Maki."

Delegitimization and marginalization: Delegitimization means making a person or entity unfit and unacceptable. Even if they are formally legal, they have been "banished from the camp." Politics is based on disagreement, contrasts, and contradictions in society. The institutional structure of society is based on these. The key to social research about these contradictions and the perception of these social contrasts is an understanding of the conditions that shape organizational and individual activity (Friedland and Alford [25 p. 256]).

Delegitimization is one of the most effective psychological mechanisms to fuel and maintain conflicts. Moreover, it is a mechanism that leads to an attribution to the rival of extreme negative values that exclude groups from the human groups that are supposed to act within accepted human limitations and norms (Bar-Tal, [26 p. 170]; [27]), with the aim of denying the rival's humanity, and can lead to physical violence against the rival (Bar-Tal \& Teichman [27]; Holt \& Silverstein [28]; Rieber [29]).

The process, directed at the Knesset representatives of the Arab population, has the following aims: The first is to continue the general delegitimization of the Arab citizens and to depict their representatives as hostile and unfit to be part of the government system in Israel, making their exclusion from the political game essential. The second goal is to intensify the exclusionary policy of the hegemonic majority and ensure the continuation of undisputed right-wing control of the country. Their delegitimization deters the public from supporting a coalition that would require their support, and thus deters Labor and some of its partners from depending on the support of Arab MKs. A third political goal of the delegitimization of the MKs of the United Arab List is to discourage Arabs from voting for it or from voting at all. ${ }^{19}$

As stated above, as active Arab representation has grown and the proportion of Arab votes cast for the Zionist parties has decreased, this process has intensified and become more dangerous. It accelerated right after the formation of the Joint Arab List. Avigdor Lieberman once said that the Arab MKs should be executed ${ }^{20}$ and has often spoken of them as a danger to the state and a fifth column. ${ }^{21}$ In a televised debate before the last elections he let loose with a violent verbal attack on the chair of the Joint List: "You are a terrorist.” This goes along with his statements against the

\footnotetext{
19 See, for example, the statement by the coalition chair (Likud), that he would prefer if Arabs did not vote at all [30].

20 Alon [31].

21 "Lieberman on the Arab MKs: 'They are more dangerous than Hamas and Jihad. They attempt to disintegrate us up from the inside. They are a fifth column that takes advantage of Israeli democracy to destroy it from the inside"” [32].
}

entire Arab sector, such as a call for a boycott of Arab businesses, ${ }^{22}$ and especially against the Arab MKs. Calling the head of the Joint List a traitor is a critical blow to the list and its voters, since this charge is the most effective of all within the Jewish sector. ${ }^{23}$

The violent language against Arab MKs continues without letup: in a Knesset speech, the former head of the General Security Service told the chair of the Joint List, "Ayman Oudeh, Yassin ${ }^{24}$ is waiting for you in hell.",25 Also in the Knsset plenum, the Deputy Interior Minister attacked the Arab citizens through their Knesset representatives: "Identity cards for Arabs? We are doing you a favor.” He turned to MK Haneen Zoabi and added, whether in condescension or as a threat: "Return your identity card. We are doing all of you a favor by allowing you to be here."26

\section{Discussion and Conclusion}

The philosophers of the social contract, who were the prophets of liberal democracy, emphasized the importance of free and open representation as a condition of substantive democracy. This underlines the importance of the principle of representation as a foundation of every democracy. In contrast, regimes not interested in an authentic and full integration of ethnic minorities in government have endeavored to distort the meaning of representation in various ways, such as microcosmos passive representation that is passive and ineffectual. This is why many thinkers have emphasized the importance of active and free representation that is accountable to the representees, their views and their interests.

This has been noted by various students of representation. Pitkin [33] emphasized representation as a form of presence ("re-presenting”). Birch [33] emphasized that only active representation is democratic and appropriate. These representatives must be the free choice of the representees, chosen in a democratic and transparent process, and accountable to their representees, who can replace them if they prove insufficiently loyal.

This makes it possible to maintain the semi-democratic model, since on the one hand the rules of the game are ostensibly democratic, while in practice the political power of the minority is stifled and it is controlled through clever tools under the guise of an ostensibly fair and democratic game.

When the Prime Minister of Israel addresses the U.S. Congress and boasts that the Arab minority has full

\footnotetext{
22 "KM Lieberman: 'Don’t buy from Arab merchants any more”" [37].

${ }^{23}$ The use of the label "traitor" against Arab MKs is not new and has been frequent among senior Likud figures.

${ }_{24}$ The reference is to Sheikh Ahmed Yassin, the Hamas leader assassinated in an Israeli airstrike.

${ }_{25}$ Azulay, M., "Ayman Oudeh, Yassin is waiting for you in hell” [36]. ${ }^{26}$ [32].
} 
democratic participation and representation in the Knesset, he is benefiting from the fruits of the semi-democratic method that distorts the substance of representation. Majority rule is perpetuated, while the rights of the minority continue to be contingent on the majority's whims and are not natural and inalienable rights, as is the case in a true democracy.

It is important to note that the semi-democratic method ensures the political system's long-term stability. The method has been employed in Israel for seventy years. Even the rights of the Arab minority have been trimmed over time, there has been no serious questioning of the rules of the game, because the minority's options are exceedingly limited but also because the majority is committed to the success and continuation of the method.

One conclusion of this study it that the majority can always chip away at the minority's rights, thanks to these representation methods and as a result of the growing delegitimization of the Arab citizens and their leadership. Statements against Arab participation in the government and even in elections and attacks on their legitimacy provide a strong basis for eroding their rights and rallying the majority group against them. The fact that the Druze are represented by three MKs in right-wing parties says it all. The vast majority of Druze hold positions incompatible with those of the right-wing parties; and in the past most reported that their satisfaction with their Knesset representation is very low (Brake $[15,16])$.

This is strong evidence of the danger of symbolic and passive representation: not only does it fail to serve citizens, it also distorts their wishes and impairs their ability to promote their authentic interests. This ostensible representation serves the preferences of the regimes of semi-democratic states, presents them as positive and enlightened, and enables them to continue to oppress the minority and violate its rights, including to equality, property, and a secure future.

\section{REFERENCES}

[1] Dahl, R. 1998. On Democracy, New Haven \& London: Yale University Press.

[2] Neuberger, B. 1998. Ha-mi'ut ha-aravi: nikur ve-hishtalvut [The Arab minority: alienation and integration], Tel Aviv: Open University.

[3] Smooha, S. 2006. "Medina yehudit o demokratia yehudit" [A Jewish state or a Jewish democracy], Mishpat U-mimshal 10 (1), 13-24.

[4] Peled, Y., Shafir, G. 2005. Being Israeli, Tel Aviv: Tel Aviv University Press.

[5] Yiftachel, O., Ghanem, A. 2004. "Understanding 'ethnocratic' regimes: the politics of seizing contested territories” Political Geography, Volume 23, Issue 6: 647-676.
[6] Smooha, S. 1997. "Ethnic Democracy: Israel as an Archetype", Israel Studies, Vol. 2, No. 2, pp. 198-241.

[7] Montesquieu, S. 1914. 'The Spirit of Laws, (Translated by Thomas Nugent, Revised by J.V. Prichard), London: G. Bell \& Sons.

[8] Elfson, W., Woods, J., Todd, W. (eds.) 1996. The Writing and Speeches of Edmund Burke, Oxford: Oxford University Press, vol. 3, pp. 132-133; pp. 144-153.

[9] Philips, A. 1995. The Politics of Presence, Oxford: Clarendon Press.

[10] Ruedin, D. 2013. Why Aren't They There? Colchester: ECPR Press.

[11] Birch, A. 2007.The Concepts \& Theories of Modern Democracy ( $3^{\text {rd }}$ ed.), London \& New York: Routledge.

[12] Birch, A. 1964. Representative and Responsible Government, London: Allen and Unwin.

[13] Pitkin, H. 1969. Representation, New York: Atherton Press.

[14] Pitkin, H. 1972. The Concept of Representation, Berkeley: University of California Press.

[15] Brake, S. 2007. "Ha-ma’arekhet ha-politit ha-arvit: ihud, pirud, ve-hishtatfut," in Rekhess, E. (ed.), Ha-mi'ut ha-aravi be-yisrael veha-behirot la-keneset ha-17 [The Arab minority in Israel and the elections for the $17^{\text {th }}$ Knesset], Tel Aviv: Dayan Center and Conrad Adenauer Foundation Press, Tel Aviv University, 22-39.

[16] Brake, S. 2010. "Meni'ei ha-druzim ba-behirot la-keneset” [The motivations of the Druze in Knesset elections], in: Lavie, E., and Rudnitzky, A., (ed.), Politika, behirot, ve-shilton mekomi ba-yishuv ha-aravi veha-druzi be-yisrael [Politics, elections, and local government in the Arab and Druze communities in Israel], Tel Aviv: Moshe Dayan Center for Middle East and African Studies Press, Tel Aviv University, 159-192.

[17] Baumel, Y. 2007. Tzel Kahol Lavan [Blue and white shadow], Pardes Press, Haifa.

[18] Osazki-Lazar, S., Boimel, Y. 2014 "In the Shadow of Marital Law" in Hahevra Haarabit Beysrael [Arab Society in Israel], Raanana, The Open University of Israel.

[19] Zoubi, S., 1987. Shahad 'iyan-biographia ishit [Shahad Iyan—a biography] Shefaram: Dar al-Nahdah.

[20] Scott, C. J. 1972. Comparative Political Corruption, Englewood Cliffs: Prentice-Hall.

[21] Benziman, U., and Mansour, A. 1992. Dayarei mishne: arviyey Yisrael ma'amadam veha-midiniut kalpeihem [Subtenants: the Arabs of Israel, their status and the policy towards them], Jerusalem: Keter

[22] Knesset Research and Information Center 2015. Letter dated July 2.

[23] Baumel, Y. 2002. "Yahaso shel ha-mimsad ha-yisre’eli la-aravim be-yisrael: mediniyut, eqronot, u-fe'ulot: he-asor ha-sheni, 1958-1968" [The Israeli establishment's attitude to the Arabs in Israel: policy, principles, and activities: the second decade, 1958-1968]. Doctoral dissertation, University of Haifa. 
[24] Kremnitzer, M. 2005. Pesilat reshimot [Disqualification of lists], Jerusalem: Israel Democracy Institute.

[25] Friedland, R., Alford, R. 1991. "Bringing Society Back In: Symbols, Practices, and Institutional Contradictions," in The New Institutionalism in Organizational Analysis, Walter P., DiMaggio, P. (eds.), Chicago: University of Chicago Press, pp. 232-263.

[26] Bar-Tal, D. 1989. "Delegitimization: The Extreme Case of Stereo-typing and Prejudice"' in: Bar-Tal, D., Grauman, C., Kruglanski, A., Stroebe, W. (eds.) Stereotyping and Prejudice: Changing Conceptions, New York: Springer, pp. 169-188.

[27] Bar-Tal, D., Teichman, Y. 2005. Stereotypes and Prejudice in Conflict: Arab Representation in the Israeli Jewish Society. Cambridge: Cambridge University Press.

[28] Holt, R., Silverstein, B. 1989. "In the Psychology of the Enemy Images: Introduction and Overview", Journal of Social Issues, Vol.45, No. 2, pp. 1-11.

[29] Rieber, L. 1991 "Animation, Incidental Learning, and Continuing Motivation", Journal of Educational Psychology, Vol. 83, No. 3, pp. 318-328.
[30] Ha'aretz, December 10, 2016, http://www.haaretz.co.il/news/politi/1.3148438.

[31] Alon, G. 2006. "Lieberman kara le-hotzi la-horeg havrei keneset aravim; havrei keneset Tibi, Barake, ve-Galon: zo hatarat dam" [Lieberman called for executing Arab MKs; MKs Tibi, Barakeh, and Galon: This is a License to Kill], TheMarker, May 4.

[32] Ynet, 2012. "Deputy Minister: ID for Arabs? We do you a Favor; Netanyahu to Arab MKs: You are Hypocrite""', http://www.ynet.co.il/articles/0,7340,L-4672109,00.html.

[33] Ynet, 2015. "Liberman on Arab MKs: More Dangerous than Hamas and Jerad", http://www.ynet.co.il/articles/0,7340,L-4709241,00.html.

[34] Walla News, 2015. "KM Lieberman: 'Don’t buy from Arab merchants any more'", http://news.walla.co.il/item/2894847.

[35] Brake, S. 2009. Seker emdot ha-druzim be-yisrael [Survey of the positions of the Druze in Israel], survey commissioned by Druze leaders in Israel.

[36] Azulay, M., "Ayman Oudeh, Yassin is waiting for you in hell” (Ynet, March 28 2016). 